\title{
Produksi dan Kandungan Nutrien Beberapa Varietas Sorgum Hybrid dengan Jarak Tanam Berbeda sebagai Sumber Pakan
}

\author{
Hajar $^{1}$, L Abdulah¹, D Diapari ${ }^{1}$
}

Corresponding email:

hajar93nwezard@gmail.com

'Department of Animal Nutrition and Feed Technology, Faculty of Animal Science, IPB University (Bogor Agricultural University)

\section{ABSTRACT}

Sorghum feed is a type of cereal plant that has potential use as animal feed or forage. The reseach aim was to evaluate production and nutritional quality of some sorghum hybrid varieties, and determined the optimal spacing of sorghum plants. This research was arranged in a factorial randomized block design with 6 treatments and four replications. The first factor was the varieties of 12FS9006, 13 FB7 001 and $12 S 49001$. The second factor was space of $25 \times 25 \mathrm{~cm}$ and $25 \times 40 \mathrm{~cm}$. The variables were fresh and dry matter of biomass production and also nutrient (ash, crude fiber, crude protein, Neutral Detergen Fiber and Acid Detergen Fiber. Sorghum varieties had significant effect $(\mathrm{p}<0.05)$ to fresh biomass production, dry matter biomass production, ash, crude fiber and crude protein). The space had a significant effect $(p<0.05)$ to the dry matter production of biomass and crude fiber. The average variety of fresh biomass plant production was (18.90 tons ha-1), dry matter production of biomass was (4 ton ha-1), ash (5.51\%), crude fiber (30.90\%) and crude protein $(8.45 \%)$. The average dry matter production was 4.34 tons ha- 1 and crude fiber $29.96 \%$. It can be concluded that the highest production and the best nutrient quality of sorghum hybrid was obtained at the sorghum variety of $12 \mathrm{~S} 49001$, the distance of $25 \times 25 \mathrm{~cm}$ was the best plant space for hybrid sorghum production.

Keywords: hybrid varieties, nutrient, plantspace, production

\section{ABSTRAK}

Sorgum pakan merupakan jenis tanaman sereal yang berpotensi sebagai makanan ternak. Penelitian ini bertujuan untuk mengevaluasi produksi dan kualitas nutrien beberapa varietas sorgum hybrid, serta menetapkan jarak tanam yang optimal pada tanaman sorgum. Penelitian ini menggunakan rancangan kelompok pola faktorial dengan dua faktor dan empat ulangan. Faktor pertama adalah varietas 12FS9006, 13 FB7001 dan 12S49001. Faktor kedua adalah jarak tanam $25 \times 25 \mathrm{~cm}$ dan $25 \times 40 \mathrm{~cm}$. Peubah yang diamati adalah produksi biomasa segar, produksi biomasa bahan kering dan kualitas nutrien (abu, serat kasar, protein kasar, NDF (Neutral Detergen Fiber) dan ADF(Acid Detergen Fiber). Varietas sorgum berpengaruh $(\mathrm{p}<0,05)$ terhadap produksi biomassa segar,produksi biomasa bahan kering, abu, serat kasar dan protein kasar). Jarak tanam berpengaruh $(p<0,05)$ terhadap produksi bahan kering dan serat kasar. Rataan varietas produksi biomasa segar sebesar 18,90 ton $\mathrm{ha}^{-1}$, produksi biomasa bahan kering sebesar 4 ton $\mathrm{ha}^{-1}$, abu 5,51\%, serat kasar $30,90 \%$ dan protein kasar 8,45\%. Rataan jarak tanam produksi bahan kering sebesar 4,34 ton ha ${ }^{-1}$ dan serat kasar 29,96\%. Simpulan hasil penelitian bahwa produksi tertinggi terdapat pada varietas sorgum 12S49001, kualitas nutrien yang baik pada varietas sorgum 12S49001. Jarak tanam 25x25cm merupakan jarak tanam yang optimal untuk produksi sorgum hybrid.

Kata kunci: jarak tanam, nutrien, produksi,varietas sorgum hybrid 


\section{PENDAHULUAN}

Hijauan merupakan makanan ternak ruminansia. Ketersediaan sumber pakan hijauan masih sangat terbatas disebabkan sedikitnya lahan yang tersedia untuk pengembangan produksi hijauan. Menurut Puteri (2015), permasalahan tersebut perlu dilakukan upaya eksploratif guna mendapatkan tanaman pakan ternak yang memilki produktivitas yang tinggi serta mampu bertahan pada kondisi lahan dan iklim di Indonesia.

Sorgum (Sorghum bicolor (L.)Moench) jenis tanaman yang berpotensi sebagai makanan ternak. Sorgum merupakan jenis tanaman serealia yang mengandung nutrisi tinggi (Dicko et al. 2005). Hijauan ini mampu memenuhi kebutuhan nutrien untuk ternak ruminansia. Kandungan nutrien sorgum yang di panen pada fase berbunga menurut Sriagtula (2016) menghasilkan kadar air 10,8\%, abu 6,70\%, Protein Kasar 8,79\%, Lemak Kasar 1,20\%, Serat Kasar 27,88\%, dan TDN 49,83\%.

Varietas sorgum berasal dari Australia telah dikembangkan di Indonesia, yaitu varietas hybrid 20, varietas 12FS5006, varietas 13FB7001 dan varietas 12S49001. Kualitas gandum serta sorgum lokal masih sangat rendah dibandingkan impor, sehingga perlu dilakukan upaya program pemuliaan tanaman (Soeranto 2011).

Upaya untuk meningkatkan produksi hijauan pakan memerlukan manajemen sumberdaya lahan yang tepat. Penggunaan lahan yang tepat seperti pengaturan jarak tanam sangat berkaitan dengan pertumbuhan dan produksi. Jarak tanam merupakan faktor penting untuk teknik penanaman tanaman karena mempengaruhi populasi tanaman dan produksi yang dihasilkan (Lemerle et al. 2006; McMurray 2004; McRae et al. 2008).

Tujuan dari penelitian adalah mengevaluasi produksi dan nutrisi pada beberapa varietas sorgum hybrid dengan jarak tanam berbeda sebagai sumber pakan dan menetapkan jarak tanam yang optimal pada tanaman sorgum sebagai pakan ternak.

\section{METODE}

\section{Alat dan Bahan}

Peralatan yang digunakan adalah meteran, hack tractor mini, timbangan, oven, dan mesin penggiling (grinder). Bahan yang digunakan adalah bibit sorgum dari varietas hybrid 12FS9006,varietas 13FB7001dan varietas13S4 9001, pupuk kandang (feses sapi), NPK dan kapur dolomit.

\section{Alat dan Bahan}

Pelaksanaan penelitian dimulai dengan mengambil sampel tanah, kemudian dilakukan pembajakan untuk memecahkan bongkahan tanah, dua hari setelah pengolahan tanah selanjutnya dilakukan pemupukan, dua belas hari setelah pemupukan dilakukan pengapuran dan pencangkulan sebelum penanaman. Lima belas hari setelah pengolahan tanah dilakukan penanaman bibit pada petakan berukuran $4 \times 4 \mathrm{~m}$ dengan jarak tanam yaitu $25 \times 25 \mathrm{~cm}$ dan $25 \times 40 \mathrm{~cm}$. Setelah berusia 21 hari (Made 2017) dipupuk menggunakan pupuk NPK. Pemeliharaan dilakukan dengan penyiraman tanaman dua kali sehari dan pembersihan gulma pada plot penanaman. Pemanenan dilakukan pada umur tanaman 95 hari (Putri 2015). Biomassa tanaman ditimbang untuk mengetahui produksi total pada plot, kemudian dijemur dibawah sinar matahari selama dua hari, dikeringkan menggunakan oven dengan suhu $60^{\circ} \mathrm{C}$ selama 48 jam untuk mendapatkan bobot kering. Sampel digiling menjadi tepung dengan ukuran $1 \mathrm{~mm}$ dan siap dianalisis untuk menentukan nutriennya.

\section{Rancangan Percobaan dan Analisis Data}

Rancangan percobaan yang digunakan adalah Rancangan Acak Kelompok Faktorial 3x2 dengan 2 faktor dan 4 kali ulangan. Faktor pertama adalah varietas sorgum hybrid yang terdiri dari varietas 12FS5006, varietas 13FB7001 dan varietas $12 \mathrm{~S} 49001$. Faktor kedua adalah jarak tanam $25 \times 25 \mathrm{~cm}$ dan $25 \times 40 \mathrm{~cm}$.

Data dianalisis menggunakan sidik ragam (ANOVA). Apabila perlakuan berpengaruh nyata, maka dilanjutkan dengan uji Tukey. Analisis data dilakukan menggunakan software statistik SAS 9.4. Pengujian dilakukan pada taraf nyata $5 \%$ dan $1 \%$.

Peubah yang diamati adalah produksi biomassa segar dengan menimbang tanaman setelah dilakukan pemotongan dengan panjang $\pm 10 \mathrm{~cm}$ di atas permukaan tanah, dan kualitas nutrien (abu, serat kasar, protein kasar) dengan metode proksimat (AOAC 2005), NDF (Neutral Detergen Fiber) dan ADF (Acid Detergen Fiber) menggunakan metode Van Soest (1991)

\section{HASIL DAN PEMBAHASAN}

\section{Produksi Biomassa}

Produksi biomassa segar menunjukkan tingkat serapan air dan unsur hara oleh tanaman untuk proses metabolisme. Biomassa sorgum dapat diperoleh dari batang, daun, akar, dan biji. Data produksi dan potensi biomassa bagian atas segar, batang segar, dan daun segar disajikan pada Tabel 1.

Tabel 1 Produksi biomassa segar ton ha ${ }^{-1}$ tiga varietas sorgum hybrid

\begin{tabular}{llll}
\hline \multirow{2}{*}{ Varietas } & \multicolumn{3}{c}{ Jarak $(\mathrm{cm})$} \\
\cline { 2 - 4 } 12 FS9006 & $16 \times 25$ & $25 \times 40$ & Rataan \\
13 FB7001 & $14,05 \pm 4,82$ & $9,54 \pm 4,00$ & $11,79 \pm 4,76^{\text {b }}$ \\
12 S49001 & $21,54 \pm 8,39$ & $16,25 \pm 4,65$ & $18,90 \pm 6,89^{\text {a }}$ \\
\hline Rataan & $17,20 \pm 6,65$ & $13,22 \pm 4,68$ & \\
\hline
\end{tabular}

Superskrip yang berbeda pada kolom yang sama menunjukkan perbedaan nyata $(P<0,05)$ 
Tabel 2 Produksi biomassa bahan kering ton $\mathrm{ha}^{-1}$ tiga varietas sorgum hybrid

\begin{tabular}{|c|c|c|c|}
\hline \multirow{2}{*}{ Varietas } & \multicolumn{2}{|c|}{ Jarak (cm) } & \multirow[b]{2}{*}{ Rataan } \\
\hline & $25 \times 25$ & $25 \times 40$ & \\
\hline $12 F S 9006$ & $4,31 \pm 1,04$ & $2,62 \pm 0,04$ & $3,47 \pm 1,31^{a b}$ \\
\hline 13FB7001 & $3,20 \pm 1,45$ & $1,01 \pm 0,53$ & $2,11 \pm 1,54^{\mathrm{b}}$ \\
\hline $12 S 49001$ & $5,50 \pm 0,99$ & $2,49 \pm 0,75$ & $4,00 \pm 1,82^{a}$ \\
\hline Rataan & $4,34 \pm 1,42^{a}$ & $2,04 \pm 0,90^{b}$ & \\
\hline
\end{tabular}

Superskrip yang berbeda pada kolom dan baris yang sama menunjukkan perbedaan nyata $(\mathrm{P}<0,05)$

Interaksi antara varietas sorgum hybrid dan jarak tanam tidak berpengaruh terhadap produksi biomassa segar. Produksi biomassa segar berpengaruh nyata $(\mathrm{p}<0,05)$ oleh varietas. Produksi biomassa tertinggi dihasilkan dari varietas $12 \mathrm{~S} 49001$ sebesar $18,9 \mathrm{kgha}^{-1}$ dan varietas 12FS9006 sebesar 14,93 $\mathrm{kgha}^{-1}$. Varietas yang memiliki produksi terendah adalah 13FB7001 yaitu 11,79 $\mathrm{kgha}^{-1}$. Hal ini diduga varietas $12 S 49001$ memiliki pertumbuhan yang tinggi dan jumlah daun yang tinggi. Menurut Haryadi et al. (2015) produksi biomassa yang tinggi bila unsur hara yang ada dalam tanah mampu diserap dalam jumlah yang cukup sehingga memacu perkembangan organ pada tanaman. Hal ini sejalan dengan penelitian Rahma (2014) bahwa meningkatnya biomassa dikarenakan tanaman menyerap air dan unsur hara yang lebih banyak.

Interaksi antara varietas sorgum hybrid dan jarak tanam tidak berpengaruh terhadap produksi bahan kering (Tabel 2). Produksi bahan kering nyata dipengaruhi $(p<0,05)$ oleh varietas. Produksi bahan kering tertinggi dihasilkan oleh varietas $12 \mathrm{~S} 49001$ sebesar 4 kg ha-1 dan 12 FS9006 sebesar 3,47 kg ha-1. Varietas yang memiliki produksi bahan kering yang rendah yaitu varietas 13 FB7001 sebesar 2,11 kg ha-1. Hal ini diduga varietas $12 S 49001$ memiliki produksi biomassa, pertumbuhan batang dan daun yang tinggi. Menurut Haryadi et al. (2015) bahwa perkembangan organ tanaman seperti akar dapat menyerap hara dan air lebih banyak yang akan disalurkan ke bagian tanaman lainnya, sehingga mampu memenuhi fungsinya, selanjutnya aktivitas fotosintesis akan meningkat dan mempengaruhi bobot segar dan bobot kering. Menurut Kurniawan (2014) banyak faktor yang mempengaruhi produksi bahan kering tanaman sorgum, namun faktor genetik dan lingkungan merupakan faktor utama yang mempengaruhinya.

Jarak tanam mempengaruhi $(\mathrm{p}<0,05)$ produksi bahan kering. Produksi bahan kering tertinggi dihasilkan oleh jarak tanam 25x25 cm sebesar 4,34 kg ha-1 kemudian diikuti jarak tanam $25 \times 40 \mathrm{~cm}$ sebesar 2,04 kg ha-1. Hal ini diduga jarak tanam yang padat memungkinkan tanaman dapat memanfaatkan faktor tumbuh sehingga tanamannya dapat tumbuh dan mendapatkan hasil yang
Tabel 3 Komposisi nutrien pada tiga varietas sorgum hybrid

\begin{tabular}{|c|c|c|c|c|}
\hline \multirow{2}{*}{ Parameter } & \multirow{2}{*}{ Varietas } & \multicolumn{3}{|c|}{ Jarak (cm) } \\
\hline & & $25 \times 25$ & $25 \times 40$ & Rataan \\
\hline & $12 \mathrm{FS} 9006$ & $4,20 \pm 0,83$ & $4,19 \pm 0,73$ & $4,19 \pm 0,70^{\mathrm{ab}}$ \\
\hline \multirow[t]{4}{*}{ Abu (\%) } & $13 F B 7001$ & $3,94 \pm 0,42$ & $3,73 \pm 0,34$ & $3,83 \pm 0,36^{b}$ \\
\hline & $12 S 49001$ & $5,44 \pm 1,33$ & $5,59 \pm 0,34$ & $5,51 \pm 0,87^{a}$ \\
\hline & Rataan & $4,52 \pm 1,01$ & $4,50 \pm 0,95$ & \\
\hline & $12 F S 9006$ & $6,62 \pm 1,18$ & $7,82 \pm 0,59$ & $7,22 \pm 1,07^{\mathrm{ab}}$ \\
\hline Protein (\%) & 13FB7001 & $6,47 \pm 0,39$ & $7,05 \pm 1,14$ & $6,79 \pm 0,83^{b}$ \\
\hline \multirow[t]{3}{*}{ Kasar } & $12 S 49001$ & $9,18 \pm 1,14$ & $7,72 \pm 0,45$ & $8,41 \pm 1,11^{\mathrm{a}}$ \\
\hline & Rataan & $7,42 \pm 1,56$ & $7,53 \pm 0,77$ & \\
\hline & $12 F S 9006$ & $30,12 \pm 1,83$ & $26,69 \pm 0,04$ & $28,41 \pm 3,40^{a}$ \\
\hline Serat (\%) & 13FB7001 & $28,09 \pm 1,47$ & $23,01 \pm 2,58$ & $25,53 \pm 3,34^{b}$ \\
\hline \multirow[t]{2}{*}{ Kasar } & $12 S 49001$ & $31,71 \pm 4,92$ & $30,09 \pm 0,75$ & $30,90 \pm 3,27^{a}$ \\
\hline & Rataan & $29,69 \pm 3,15^{a}$ & $26,60 \pm 3,92^{b}$ & \\
\hline
\end{tabular}

Superskrip yang berbeda pada kolom dan baris yang sama menunjukkan perbedaan nyata $(P<0,05)$

lebih banyak. Menurut Febrianto et al. (2017) dan Solichatum et al. (2015) bahwa jarak tanam yang padat mampu memanfaatkan cahaya matahari, air, unsur hara dan ruang tumbuh yang mendukung pertumbuhan dan perkembangan tanaman sehingga dapat meningkatkan hasil. Hal ini sejalan dengan penelitian Ardi et al. (2016) bahwa jarak tanam yang padat populasi tanamannya mampu menurunkan laju air hujan oleh karena itu laju air hujan dipermukaan tanah menjadi lambat. Dengan demikian permukaan tanah tidak terjadi erosi.

\section{Nutrien Tanaman Sorgum Hybrid}

Nutrien merupakan unsur atau senyawa kimia yang ada dalam pakan. Data kadar nutrien tanaman pada ketiga varietas sorgum hybrid yang diamati disajikan pada Tabel 3.

Interaksi antara varietas sorgum hybrid dan jarak tanam tidak berpengaruh terhadap kadar abu. Kadar abu dipengaruhi $(\mathrm{p}<0,05)$ oleh varietas. Varietas yang menghasilkan kadar abu tertinggi varietas 12 S49001 sekitar 5,51\%. Varietas yang menghasilkan kandungan nutrien rendah yaitu varietas 13FB7001 sekitar 3,83\% dan varietas 12 FS9006 sekitar 4,19\%. Kadar abu pada penelitian lebih rendah diduga sorgum forage salah satunya dapat menurunkan kadar abu pada tanamannya yang pemanfaatanya sebagai pakan selain itu karena faktor umur panen. Kadar abu pada tanaman sorgum akan menurun dengan meningkatnya umur tanaman dilaporkan Ayub et al. (2002); Koten et al. (2012) sorgum yang dipanen pada awal berbunga lebih tinggi kandungan abunya dibanding sorgum yang dipanen pada fase kedewasaan lanjut (soft dough). Abu terdiri atas zat-zat anorganik atau mineral (Sriagtrula 2016; Sudarmadji et al. 2003).

Interaksi antara varietas sorgum hybrid dan jarak tanam tidak berpengaruh terhadap kadar protein kasar (Tabel 3). Kadar protein kasar nyata dipengaruhi 
$(\mathrm{p}<0,05)$ oleh varietas. Varietas yang menghasilkan kadar protein tertinggi yaitu varietas $12 S 49001(8,45 \%)$ dan varietas 12FS9006 (7,22\%). Varietas yang menghasilkan kadar protein kasar terendah yaitu varietas13FB7001 $(6,79 \%)$. Hal ini diduga bahwa varietas 12549001 memiliki proporsi daun yang tinggi selain itu dipengaruhi umur. Hal ini didukung dengan pernyataan (Tillman et al., 1991); (Wahyuni dan Kamaliyah, 2012), bahwa jumlah daun yang tinggi akan berpengaruh terhadap kadar protein kasar, hal ini disebabkan karena daun sebagai tempat terjadinya fotosintesis dan respirasi, tanaman yang memiliki banyak daun mengandung klorofil yang tinggi. Klorofil merupakan salah satu sumber protein.

Kadar protein kasar menurun dengan umur pemotongan yang memasuki fase generatif (Ayub et al. 2002, Butler dan Muir 2003, Miron et al. 2006, Nabi et al. 2006). Kadar protein kasar lebih rendah pada tahap kematangan, namun jumlah produksinya meningkat pada bahan kering. Menurut Nabi et al. (2006) dan Putri et al. 2016) menurunnya kadar protein kasar seiring dengan lamanya waktu panen berkaitan dengan fisiologi dari tanaman sorgum itu sendiri. Pakan yang berkualitas rendah kadar proteinnya kurang dari $<6 \%$ (Rianto dan Purbowati 2013)

Kadar serat kasar sorgum hybrid dipengaruhi $(\mathrm{p}<0,05)$ oleh varietas (Tabel 3). Interaksi antara varietas dan jarak tidak berpengaruh terhadap kadar serat kasar. Kadar serat kasar tertinggi terdapat pada varietas 12S49001sekitar 30,90\%, kemudian varietas 12FS9006 sekitar $28,41 \%$. Varietas dengan serat kasar terendah 13FB7001 sekitar 25,53\%. Diduga varietas 12 S49001 memiliki proporsi batang yang tinggi selain itu juga di pengaruhi oleh umur tanam. Hal ini didukung dengan pernyataan Wahyuni \& Kamaliyah (2012) proporsi batang yang tinggi berpengaruh terhadap kadar serat kasar, bertambahnya komponen dinding sel tanaman akan meningkatkan kadar serat kasar. Meningkatnya serat kasar bersamaan dengan meningkatnya umur suatu tanaman. Menurut Mustikowi (2006) tanaman yang cepat tua akan membentuk dinding sel tanaman yang merupakan fraksi serat kasar. Semakin tinggi kadar serat kasar semakin sulit dicerna oleh ternak.

Kadar serat kasar dipengaruh $(\mathrm{p}<0,05)$ oleh jarak tanam (Tabel 3). Kandungan serat kasar yang tinggi terdapat pada jarak tanam $25 \times 25 \mathrm{~cm}$ sebesar $29,96 \%$, hal ini diduga meningkatnya serat kasar dipengaruhi jarak tanam yang padat dikarenakan jumlah proporsi batang yang tinggi. Pernyataan ini didukung oleh Alwi (2015) jarak tanam lebih padat meningkatkan kandungan serat kasar hal ini dikarenakan proporsi batangnya meningkat, peningkatan proporsi didukung dengan pertumbuhan
Tabel 4 Fraksi serat NDF dan ADF pada tiga kultivar sorgum hybrid

\begin{tabular}{lllll}
\hline \multirow{2}{*}{ Parameter } & \multirow{2}{*}{ Varietas } & \multicolumn{3}{c}{ Jarak (cm) } \\
\cline { 3 - 5 } ADF (\%) & $125 \times 25$ & $25 \times 40$ & Rataan \\
& $13 F B 006$ & $37,57 \pm 3,76$ & $38,19 \pm 3,85$ & $37,88 \pm 3,42$ \\
& $12 S 49001$ & $37,61 \pm 2,94$ & $36,90 \pm 3,58$ & $37,26 \pm 2,95$ \\
& Rataan & $36,97 \pm 4,19$ & $31,28 \pm 2,56$ & $33,50 \pm 3,95$ \\
\hline \multirow{4}{*}{ NDF (\%) } & $12 F S 9006$ & $64,94 \pm 2,21$ & $63,12 \pm 6,00$ & $64,04 \pm 4,17$ \\
& 13FB7001 & $63,82 \pm 3,34$ & $62,89 \pm 7,71$ & $63,36 \pm 5,34$ \\
& 12S49001 & $66,57 \pm 5,37$ & $62,29 \pm 4,59$ & $64,43 \pm 5,05$ \\
\hline
\end{tabular}

Superskrip yang berbeda pada kolom yang sama menunjukkan perbedaan nyata $(P<0,05)$

fisik tanaman dengan bertambahnya komponen dinding sel tanaman. Pakan yang berkualitas rendah mempunyai kadar serat kasar lebih dari 28\% atau 34\% (Rianto dan Purbowati 2013). ADF menggambarkan bagian yang tidak dapat dicerna dan NDF dapat dicerna pada hijauan (Linn dan Martin 1991). Fraksi serat ADF dan NDF tidak dipengaruh $(p>0,05)$ oleh varietas (Tabel 4$)$. Fraksi serat ADF pada varietas 12 FS9006 $(37,88 \%)$, varietas 13FB7001 (37,26\%) dan varietas $12 S 49001(33,50 \%)$. Fraksi serat NDF pada varietas $12 S 49001(64,43 \%)$, varietas 12 FS9006 $(64,04 \%)$ dan varietas 13 FB7001 $(63,36 \%)$.

Kandungan ADF dan NDF pada penelitian ini lebih rendah dari penelitian (Kurniawan et al. 2014) yaitu kadar NDF berkisar antara 68,94 \% sampai 72,07 \% dan kadar ADF berkisar antara 38,51 \% sampai 51,92 \% pada umur 35 HST. Semakin tua umur tanaman, maka lignifikasi pada dinding akan semakin tinggi. Meningkatnya dinding sel akan menurunkan jumlah karbohidrat, serat yang berkaitan dengan dinding sel/NDF. Menurut (Subramanian 2013) faktor lain yang menyebabkan kadar ADF rendah pada batang dikarenakan meningkatnya kadar gula pada batang. Pakan yang berkualitas rendah kandungan NDF kurang dari $40 \%$ dan ADF kurang dari 31\% (Redfearn \& Zhang 2016).

\section{SIMPULAN}

Produksi biomassa segar dan produksi bahan kering pada varietas 12 S49001 lebih tinggi dibandingkan dengan varietas 12FS9006 dan varietas 13FB7001. Jarak tanam $25 \times 25 \mathrm{~cm}$ lebih baik dibandingkan dengan jarak tanam $25 \times 40 \mathrm{~cm}$. Nutrien yang paling baik terdapat pada varietas 12S49001 dibandingkan dengan varietas lain.

\section{DAFTAR PUSTAKA}

Ardi DW,Gembong H \&Yulia ES. 2016. Pengaruh jumlah tanaman perlubang dan jarak tanam terhadap hasil anaman kacang tanah (Arachis Hypogea L. var. Kancil. VIGOR: Jurnal Ilmu Pertanian Tropika dan Subtropika. 3 (1): 5 -8 
Ayub M, Nadeem MA, Tanveer A \& Husnain A. 2002. Effect of different levels of nitrogen and harvesting times on the growth, yield and quality of sorghum fodder. Asian Journal of Plant Science. 1 (4): 304-307

Butler TJ, \& Muir JP. 2003. Row spacing and maturity of forage sorghum silage in north central Texas. Forage Research in Texas, http://forageresearch.tamu.edu/2003/Forage Sorghum.pdf

Purnomohadi M. 2006 Potensi penggunaan beberapa varietas sorgum manis (Sorghum bicolor (L.)Moench) sebagai tanaman pakan. Berkala Penelitian Hayati: 12: 41-44

Dicko MH, Gruppen H, Traore AS, Van Berkel WJH \& Voragen AG.2005. Evaluation of the effect of germination on phenolic compounds and antioxidant activities in sorghum varieties. Journal Agricultural and FoodChemistry. 53(7):2581-2588.

Febriyono R, Eko YS \& Suprapto A. 2017. Peningkatan hasil tanaman kangkung darat (Ipomoea reptans L.) melalui perlakuan jarak tanam dan jumlah tanaman per lubang. Jurnal Ilmu Pertanian Tropika dan Subtropika (Vigor). 2 (1): 22-27

Haryadi D, Yetti H \&Yoseva S. 2015. Pengaruh pemberian beberapa jenis pupuk terhadap pertumbuhan dan produksi tanaman Kailan (Brassica alboglabra L). Jurnal Online Mahasiswa Fakultas Pertanian. 2(2):1-10

Lemerle D, Verbeek B \& Diffy S. 2006. Influence of field pea (Pisum sativum) density on grain yield and competitiveness with annual rye grass (Lolium rigidum) in south eastern Australia. Australian Journal of Experimental Agriculture. 46 (11): 14651472.

Koten B, Soetrisno R, Ngadiyono N \& Suwignyo B. 2012. Production of sorghum plant (Sorghum bicolor (L.) Moench) of rote local variety as forage for ruminant feed at different of harvest time and urea level. BuletinPeternakan.36(3):150-155.

Kurniawan W.2014. Potential values of numbu, cty-33 and bmr sorghum as feed grown in ultisol sedimentation soil with different levels of organic fertilizer. [tesis]. Bogor (ID): Institut Pertanian Bogor.

Linn JG \& Martin NP. 1991. Forage quality analysis and interpretation. Veterinary Clinics of North America. Food Animal Practice. 7(2):509-23.

Made DG. 2017. Pertumbuhan dan produksi beberapa varietas tanaman sorgum pakan hijauan hybridpada sistem monokultur. [skripsi]. Bogor (ID): Institut Pertanian Bogor

McMurray L. 2004. Plant density inputs Kaspa field pea's grain yield. Australian Farm Journal.45-46.

McRae FJ, McCaffery DW \& Mathews PW. 2008. Winter crop variety sowing guide. NSW, Department of Primary Industries, 74-85.

Miron J, Solomon R, Adin G, Nir U, Nikbachat M, Yosef E, Carmi A, Weinberg ZG, Kipnis T, Zuckerman E \& Ben GD. 2006. Effects of harvest stage and re-growth on yield, composition, ensilage and invitro digestibility of new forage sorghum varieties. Journal of the Science of Food and Agricultural.86(1):140-147.

Nabi CG, Riaz M \& Ahmad G. 2006. Comparison of some advanced lines of Sorghum bicolor L. Monech for green fodder/dry matter yields and morpho-economic parameters. Journal of Agricultural Research.44(3):191-196.

Puteri ER. 2015. Productivity and nutrient content of some sorghum mutant lines at different cutting age levels. [tesis]. Bogor (ID): Bogor Agricultural University.

Rahma A. 2014. Pengaruh pupuk organik cair berbahan dasar limbah sawi putih (Brassica chinensis L) terhadap pertumbuhan tanaman jagung manis (Zea mays L. var. saccaharata). Laporan penelitian. Universitas Diponegoro.

Redfearn D \& Zhang H. 2016. Forage quality interpretations. Oklahoma Cooprative Extension Service. PPS-2117.

Rianto E \& Purbowati E. 2013. Paduan Lengkap Sapi Potong. Penerbar Swadaya. Jakarta.

Rosser CL, Gorka P, Beattie AD, Block HC, Mckinnon JJ, Lardner HA \& Penner GB. 2013. Effect of maturity at harvest on yield, chemical composition, and in situ degradability for annual cereals used for swath grazing. Journal of Animal Science. 91(8) :3815-3826.

Sihono 2013. Uji adaptasi galur mutan harapan sorgum manis hasi iradiasi di CTY33 Bogor. Prosiding Seminar Nasional Sains dan Teknologi Nuklir PTNBR - BATAN Bandung.

Soeranto H. 2011. Riset dan pengembangan sorgum dan gandum untuk ketahanan pangan. Pusat Aplikasi Teknologi Isotop dan Radiasi. Badan Tenaga Nuklir Nasional (Batan)
Solichatun, Anggarwula E \& Mudyantini N. 2005. Pengaruh ketersediaan air terhadap pertumbuhan dan kandungan bahan aktif saponin tanaman ginseng jawa(Talinum paniculatum Gaertn.) http://biosains.mipa.uns.ac.id/F/F0302/F030203.pdf. Diunduh 6 Juli 2018

Sriagtula R. 2016. Growth biomass and nutrient production of brown Midrib sorghum mutant lines at different harvest time. [dissertation]. Bogor (ID): Bogor Agricultural University.

Subramanian SK. 2013. Agronomical, physiological and biochemical approaches to characterize sweet sorghum genotypes for biofuel production. [dissertation]. Kansas State University, Manhattan. Kansas.

Sudarmadji S. Haryono B \& Suhardi. 2003. Analisa Bahan Makanan dan Pertanian. Liberty Yogyakarta bekerja sama dengan Pusat Antar Universitas Pangan dan Gizi Universitas Gadjah Mada. Yogyakarta.

Susilowati YE. 2011. Pengaruh jarak tanam dan jumlah biji perlubang tanam terhadap hasil baby corn. Jurnal Inovasi. LPPM Universitas Tidar Magelang. 36 (2) : 52 - 63.

Tillman AD, Hartadi H, Reksohadiprojo S, Prawirokoesoemo S \& Lebdosoekojo S. 1991. Ilmu Makanan Ternak Dasar. Edisi ke-5. Gadjah Mada University Press, Yogyakarta. 